\title{
Polyphase white mica growth in low-grade metapelites from La Cébila Me- tamorphic Complex (Famatinian Belt, Argentina): evidence from microstructural and XRD investigations
}

\author{
Sebastián O. Verdecchiaa ${ }^{1}$ Gilda Collo ${ }^{1}$, Edgardo G. Baldo ${ }^{1}$ \\ I CICTERRA-Consejo Nacional de Investigaciones Cientificas y Técnicas (CONICET)-Universidad Nacional de Córdoba, Facultad \\ de Ciencias Exactas, Físicas y Naturales, Av. Vélez Sarsfields 1611, CP. X5016GCA Córdoba, Argentina. \\ sverdecchia@efn.uncor.edu; gcollo@efn.uncor.edu; ebaldo@efn.uncor.edu
}

\begin{abstract}
Two tectono-thermal metamorphic events, $M_{1}-D_{1}\left(S_{1}\right.$, with associated white mica and chlorite: $\left.\mathrm{WM}_{1}-\mathrm{Chl}_{1}\right)$ and $\mathrm{M}_{2}-\mathrm{D}_{2}\left(\mathrm{~S}_{2}\right.$, with development of $\left.\mathrm{WM}_{2}-\mathrm{Chl}_{2}\right)$, are established from polyphase white mica growth for low-grade units from the Ordovician metasedimentary successions of La Cébila Metamorphic Complex in the Famatinian belt (western-central Argentina). The thermobarometric characterization of the $\mathrm{M}_{1}$ main event was carried out by means of clay-mineral analysis and crystallo-chemical parameter measurements. Epizonal (temperatures between 300 and $400^{\circ} \mathrm{C}$ ) and low-pressure conditions are suggested for $\mathrm{M}_{1}$ event, based in Kübler index values ranging from 0.23 to $0.17 \Delta^{\circ} 2 \theta$, white mica $b$ parameter values between 9.004 and $9.022 \AA$ (mean of 9.014 $\AA, n=16)$ and $\mathrm{Si}$ contents between 3.13-3.29 a.p.f.u. Temperatures of $\sim 180-270^{\circ} \mathrm{C}$ are estimated for the $\mathrm{M}_{2}$ event, with Kübler index values ranging from 0.31 to $0.46 \Delta^{\circ} 2 \theta$. The $M_{1}-D_{1}$ event of La Cébila could be linked to highstrain heating tectono-metamorphic Ordovician regime recorded in others complexes from Famatinian foreland region of Sierras Pampeanas.
\end{abstract}

Keywords: Sierras Pampeanas, Low pressure, Kübler index, White mica b parameter.

RESUMEN. Crecimiento polifásico de mica blanca en metapelitas de bajo grado del Complejo Metamórfico La Cébila (Faja Famatiniana, Argentina): evidencias a partir de investigaciones microestructurales y de DRX. Dos eventos tectono-metamórficos fueron establecidos a partir de la blastesis superpuesta de mica blanca en sucesiones metasedimentarias ordovícicas de bajo grado del Complejo Metamórfico La Cébila, cinturón Famatiniano (centro oeste de Argentina): $\mathrm{M}_{1}-\mathrm{D}_{1}\left(\mathrm{~S}_{1}\right.$, con blastesis asociada de mica blanca y clorita: $\left.\mathrm{WM}_{1}-\mathrm{Chl}_{1}\right)$ y $\mathrm{M}_{2}-\mathrm{D}_{2}$ $\left(\mathrm{S}_{2}\right.$, con desarrollo de $\left.\mathrm{WM}_{2}-\mathrm{Chl}_{2}\right)$. La caracterización termobarométrica del evento principal $\mathrm{M}_{1}$ fue llevada a cabo a través del análisis de minerales de arcilla y de la medición de parámetros cristaloquímicos. Las condiciones de

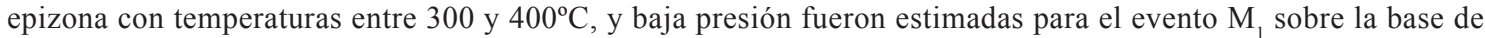
valores de índice de Kübler de 0,23 a 0,17 $\Delta^{\circ} 2 \theta$, parámetro $b$ de la mica blanca entre 9,004 y 9,022 $\AA$ (valor medio de $9,014 \AA, n=16$ ) y contenidos de Si entre 3,13-3,29 a.p.f.u. Se estimaron temperaturas de $\sim 180-270^{\circ} \mathrm{C}$ para el evento $\mathrm{M}_{2}$, con valores de índice de Kübler entre 0,31 y $0,46 \Delta^{\circ} 2 \theta$. El evento $M_{1}-D_{1}$ registrado en La Cébila podría ser vinculado al evento tectono-metamórfico ordovícico con calentamiento bajo un régimen de alta deformación ocurrido en otros complejos de la región del antepaís famatiniano de las Sierras Pampenas. 


\section{Introduction}

The Early Cambrian to Late Ordovician record of South American Central Andes comprises widespread igneous, metamorphic and sedimentary complexes forming the southwestern margin of Gondwana in the Early Paleozoic (e.g., Pankhurst and Rapela, 1998; Chew et al., 2007; Ramos, 2008). In the central and northwestern regions of Argentina (between $22^{\circ} \mathrm{S}$ and $33^{\circ} \mathrm{S}$ ), the Ordovician record is represented by the Famatinian orogenic belt (Aceñolaza and Toselli, 1976), with the main outcrops situated within the Puna, Cordillera Oriental and the eastern Sierras Pampeanas (Fig. 1a). Although different geotectonic contexts have been proposed for the Famatinian orogeny evolution (e.g., subduction processes followed by collision of para-autochthonous or exotic terranes; Thomas and Astini, 1996; Rapela et al., 1998; Aceñolaza et al., 2002; Ramos, 2008 and references therein; crustal shortening and extension in a mobile belt setting; Lucassen et al., 2000), most of the authors agree with the development of a complex back-arc basin with a high-thermal regime (e.g., Rapela et al., 1998; Astini and Dávila, 2004; Büttner, 2009; Coira et al., 2009). The subduction of oceanic lithosphere along the continental margin allowed the development of a widespread continental magmatic arc (Famatinian magmatism, ca. 460-480 Ma; Rapela et al., 2001; Viramonte et al., 2007 and references therein; Dahlquist et al., 2008), and of low- to medium-pressure metamorphic complexes from sedimentary protoliths and pre-Ordovician metamorphic and igneous basement (Büttner et al., 2005; Murra and Baldo, 2006; Steenken et al., 2006; Collo et al., 2008; Otamendi et al., 2008). The evolution of the arc overlapped in time with the deposition of marine and volcaniclastic successions within the associated foreland region (Late Cambrian to Middle Ordovician; Bahlburg, 1991; Astini, 2003 and references therein; Verdecchia et al., 2007).

Cébila Metamorphic Complex (previously named La Cébila Formation, González Bonorino, 1951), located within the Famatinian belt is composed of a variety of metamorphic and igneous rocks (Espizúa and Caminos, 1979; Fig. 1b), including low- to high-grade metasedimentary rocks metamorphosed under low-pressure conditions (Verdecchia, 2009). An Early Ordovician depositional age has been recently constrained for this complex (Verdecchia et al., 2007), which makes its previously assumed association with the Neoproterozoic to Early Cambrian Pampean Orogeny (e.g., Zimmermann, 2005) unlikely.

Its location, immediately east of the Famatinian volcanic arc, its well-constrained depositional age and the relative lack of data related to the tectonothermal evolution at this latitude makes the La Cébila Metamorphic Complex an interesting area for the understanding of the Famatinian foreland evolution. In this work, we present $\mathrm{X}$-ray diffraction analyses of clay minerals and crystallo-chemical parameters such as the Kübler index and white mica $b$ parameter carried out in the very low- to low-grade rocks within the La Cébila. The tectono-metamorphic events with their associated thermobarometric conditions, as well as some retrograde diagenetic processes, have been established in order to understand the post-depositional history of this complex.

\section{Geological setting}

The Early to Middle Ordovician metasedimentary rocks of La Cébila Metamorphic Complex are located in the eastern-central part of the Famatinian belt, outcropping discontinuously along the eastern edge of the sierra de Velasco (Fig. 1b). This range is mainly composed of Ordovician peraluminous to metaluminous granitic rocks (e.g., ortogneiss Antinaco complex and Mazán granite; Pankhurst et al., 2000; Toselli et al., 2007) and locally intruded by undeformed Carboniferous granitic plutons such as the San Blas, Huaco, and Sanagasta granites (Dahlquist et al., 2006; Grosse et al., 2008).

The outcrops of La Cébila Metamorphic Complex are located in: 1. quebrada de La Cébila, 2. quebrada de Cantadero, 3. quebrada de La Rioja, and 4. La puerta de Arauco (Fig. 1b). The lowgrade metamorphic successions are found in areas 1 and 2. This complex is composed of phyllites, metapsammites, quartzites, micaceous and quartzmicaceous schists, gneisses and migmatites (e.g., Espizúa and Caminos, 1979; Verdecchia, 2009). The metasedimentary rocks are intruded by Ordovician granitic plutons (e.g., Antinaco complex, 476.4 \pm 1.5 and 461 $\pm 2.2 \mathrm{Ma}$ U-Pb ID-TIMS monazite intrusion ages in quebrada de La Rioja area; De los Hoyos et al., 2008; see Fig. 1b) and discordant pegmatitic dikes (Verdecchia, 2009), are partially covered by the Carboniferous continental successions of the Trampeadero Formation (Gutiérrez and Barreda, 2006), and by Cenozoic sediments. 

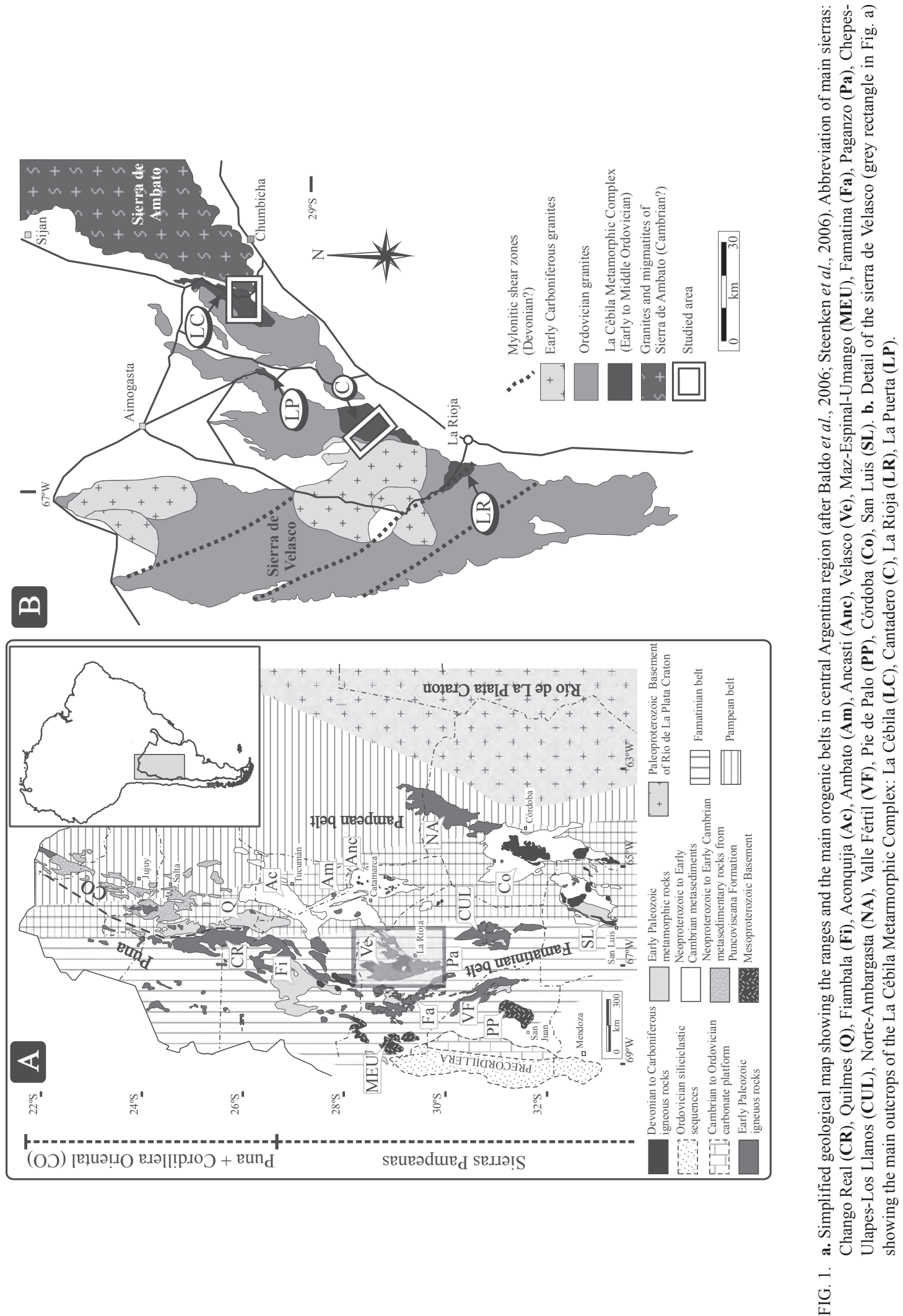
The La Cébila Metamorphic Complex was traditionally correlated with the older Puncoviscana Formation and equivalents (e.g., Zimmermann, 2005; Fig. 1a). However, the Early Ordovician primary age (Floian: 472-479 Ma; ICS Stratigraphic Chart, Ogg, 2009) of this complex has been recently established biostratigraphically in quartzites of quebrada La Cébila area (Fig. 1b; Verdecchia et al., 2007). U-Pb isotope data obtained from detrital zircon from the same lithologic unit, show Mesoproterozoic, Neoproterozoic and Cambrian ages but no Ordovician populations (cf. Rapela et al., 2007), with a minimum peak age of $\sim 530 \mathrm{Ma}$. Based on these data, the La Cébila Metamorphic Complex was interpreted as part of a shallow-water marine succession within a siliciclastic platform in the Ordovician foreland region, and coeval with the deposition of volcano-sedimentary successions of the Suri Formation associated with the volcanic arc to the west (e.g., Astini et al., 2004; Verdecchia et al., 2007). However, the absence of Ordovician zircon ages in this complex indicates sedimentation without influence of Famatinian volcanic sources (Verdecchia and Baldo, 2010). Furthermore, pre-Ordovician age populations together with geochemical analysis, compatible with acidic arc sources, obtained from this complex have been related with provenance from recycling of older units from the eastern Pampean belt and the Río de La Plata craton (Verdecchia and Baldo, 2010).

The metamorphic grade in the La Cébila Metamorphic Complex increases from very low- and low-grade in the east, to medium to high-grade toward the west in quebrada de La Cébila and quebrada de Cantadero areas (Verdecchia, 2009; Fig. 2). The very low- and low-grade metasedimentary rocks of La Cébila Metamorphic Complex comprise a succession of kilometer-thick phyllites and metapsammitic layers, with some subordinate quartzitic layers (Figs. 2, 3a, b), with a general NNE-SSW strike and NW high dip. In the quebrada de La Cébila area, the low-grade units $(\sim 2.5 \mathrm{~km}$ wide; Fig. 2 ) are in tectonic contact along a ductile shear belt with medium-grade andalusite-cordierite schists. To the SE, the low-grade succession is faulted and tectonically overlaid by the high-grade migmatites and granites of sierra de Ambato complex. In the quebrada de Cantadero area, $45 \mathrm{~km}$ southeast from quebrada de La Cébila area, the low-grade succession ( $\sim 7 \mathrm{~km}$ width; Fig. 2) grades into micaceous and quartz-micaceous schists with a biotite-cordierite parageneses.

\section{Sampling and clay mineral analysis}

Clay-size fraction $(<2 \mu \mathrm{m})$ samples for X-ray diffraction analysis were prepared following the recommendations of Moore and Reynolds (1997). The $<2 \mu \mathrm{m}$ fraction, assumed to be representative of the neoformed and transformed phases and conventionally used for main crystallographic index measurements, was separated from 14 samples of metapelites and 3 samples of fine-grained metapsammites. Clay-mineral composition was established by the comparison of orientated aggregates that were air-dried (AD), ethylene-glycol solvated (EG; 24 hours), and heated at $500^{\circ} \mathrm{C}\left(\mathrm{H}_{500} ; 4\right.$ hours). X-ray analyses were determined with Philips PW1050 (INGEIS) and X-Pert Pro (Departamento de Físico Química-UNC) diffractometers, employing Cu radiation from 4 to $30^{\circ} 2 \theta$ with a step size of $0.03^{\circ} 2 \theta$ and a count time of $0.5 \mathrm{~s}$ per step. Clay-mineral phases were semi-quantified using MIF factors and the recommendations of Moore and Reynolds (1997).

The Kübler index (KI; Kübler, 1968; Kisch, 1991) was measured in the white mica (001) reflection in both $\mathrm{AD}$ and $\mathrm{EG}$ oriented clay mineral aggregates and $\mathrm{KI}_{\mathrm{CIS}}$ values (CIS: Crystallinity Index Standard, Warr and Rice, 1994) were established from the regression equations for the diffractometers employed. The $b$ parameter of white mica (Sassi, 1972; Sassi and Scolari, 1974; Guidotti and Sassi, 1986) was measured in rock slices oriented perpendicular to the main foliation ( $\mathrm{S}_{1}$; see below); the (211) reflection of quartz, positioned at $\sim 1.541 \AA$, was used as internal standard. The chemical composition of white micas was established through SEM-EDX (Energy Dispersive X-ray spectrometry) analysis on carbon-coated polished thin sections of the studied samples. We used a Zeiss DSM950 SEM and a Variable Pressure SEM at the Centro de Instrumentación Científica (Universidad de Granada). The structural formulae of dioctahedral micas were calculated considering 22 negative charges and $0.45 \mathrm{Fe}^{3+} /\left(\mathrm{Fe}^{2+}+\mathrm{Fe}^{3+}\right)$ ratio (cf. Guidotti et al., 1994).

\section{Low-grade units in La Cébila Metamorphic Complex}

\subsection{Macrostructural characterization}

Original sedimentary bedding $\left(\mathrm{S}_{0}\right)$ is preserved in the low-grade successions and represented by a decimeter to meter thick alternating phyllite and 

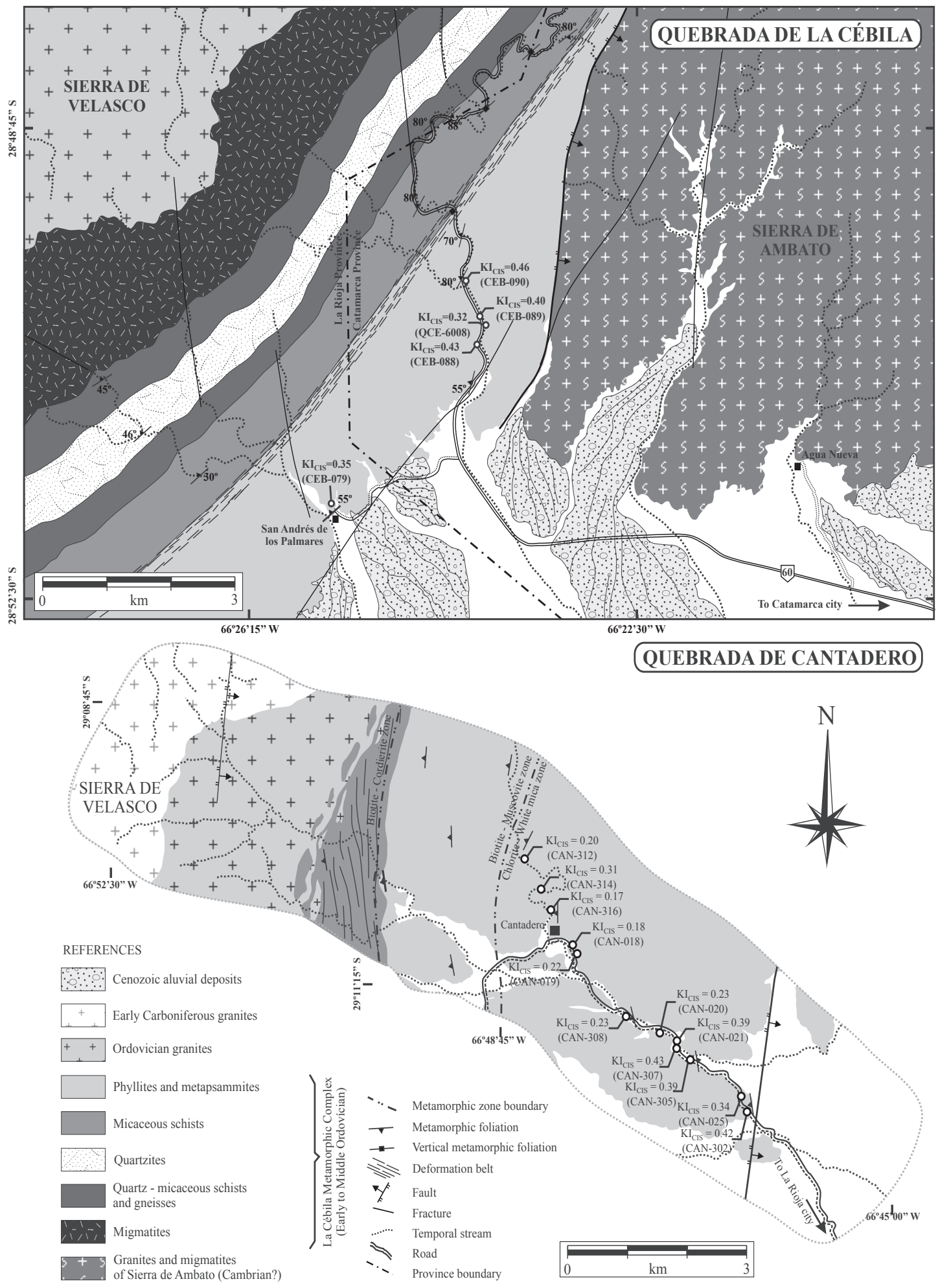

FIG. 2. Schematic geological maps of the quebrada de La Cébila and the quebrada de Cantadero areas (see white rectangle in Fig. $1 \mathrm{~b}$ for location). Sampling points and measured $\mathrm{KI}_{\mathrm{CIS}}$ values are shown. 

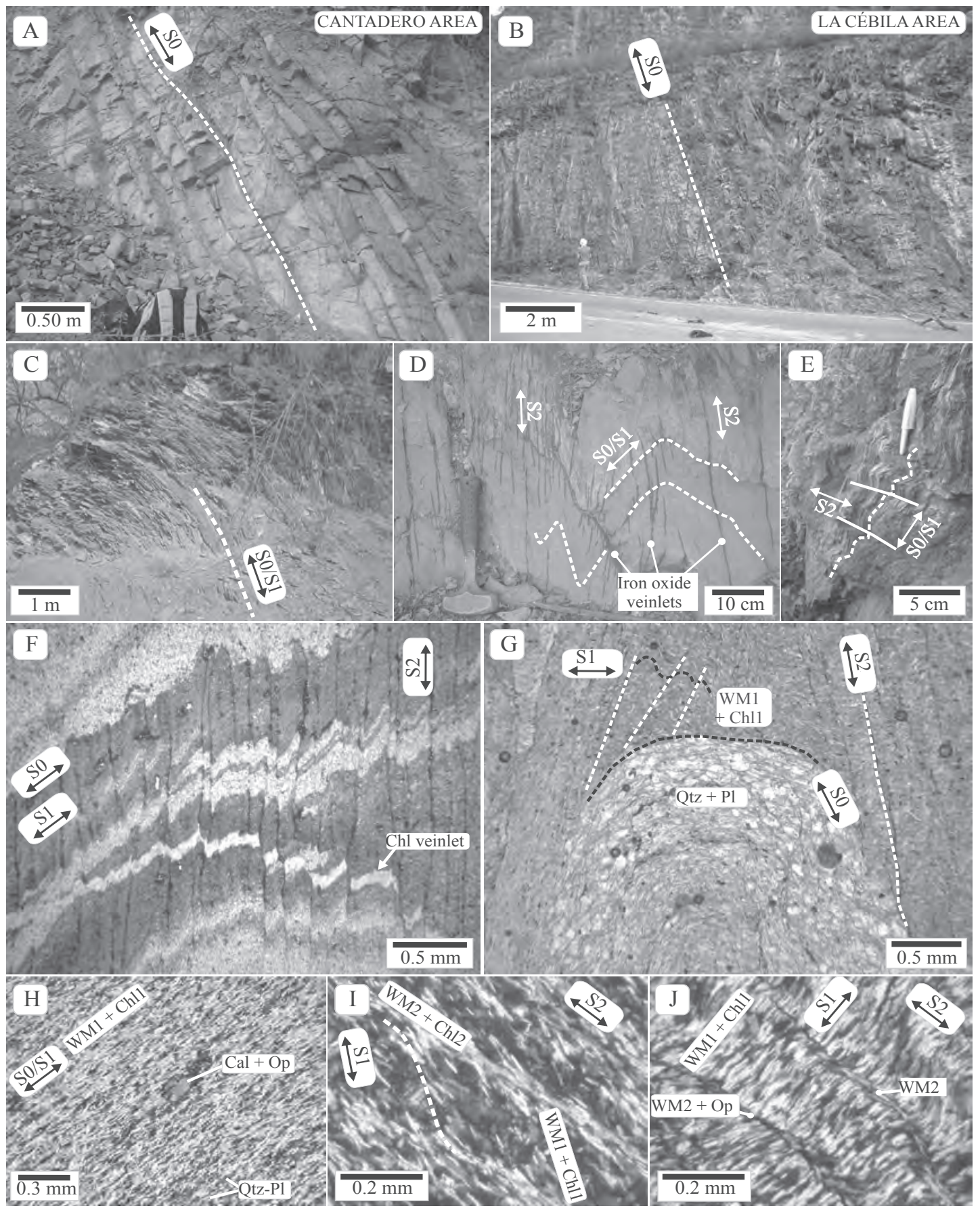

FIG. 3. a, b. Low-grade metamorphic sequences (phyllites, metapsammites and quartzites) in La Cébila Metamorphic Complex. c. $\mathrm{S}_{1}$ foliation at outcrop scale, which is strongly penetrative in phyllites. d, e. $\mathrm{S}_{2}$ axial plane foliation at outcrop scale, more pervasive in the quebrada de Cantadero area (d) than in the quebrada de La Cébila area (e). $\mathbf{f}-\mathbf{j}$. Photomicrographs of phyllites. f, g. folding of $\mathrm{S}_{0}$ (alternation of phyllosilicate and quartz-plagioclase layers) and development of $\mathrm{S}_{1}$ and $\mathrm{S}_{2}$ foliations. Note in (f) veinlets of chlorite discordant to $\mathrm{S}_{0}-\mathrm{S}_{1}$ and deformed during $\mathrm{D}_{2}\left(\mathrm{~F}_{2}-\mathrm{S}_{2}\right)$. h. Detail of $\mathrm{S}_{1}$ developing a continuous cleavage. e, f. $\mathrm{S}_{2}$ crenulation cleavage formed by orientated $\mathrm{WM}_{2}$ and $\mathrm{Chl}_{2}$. Figures $\mathbf{a}, \mathbf{c}, \mathbf{d}, \mathbf{f}, \mathbf{h}$ and $\mathbf{i}$ : quebrada de Cantadero area; $\mathbf{b}, \mathbf{e}$, $\mathbf{g}$ and $\mathbf{j}$ : quebrada de La Cébila area. 
metapsammite layers (Figs. 3a, b). These metasedimentary rocks also show two penetrative secondary foliations ( $\mathrm{S}_{1}$ and $\mathrm{S}_{2}$, Figs. 3c, d, e). The $\mathrm{S}_{1}$ foliation, predominantly subparallel to $S_{0}$ and most prominently developed, is oriented parallel to the axial surface of $F_{1}$ folds associated with a ductile deformation episode $\left(D_{1}\right)$. The $F_{1}$ folds are characterized by tight to close inter-limb angle, some meters in wavelength, and they are well developed in the metapelitic levels. This main foliation is overprinted by a weak second folding phase $\left(\mathrm{F}_{2}\right)$ with an associated crenulation foliation $\left(\mathrm{S}_{2}\right)$, subparallel to $\mathrm{S}_{1}$.

\subsection{Petrography}

The phyllites are characterized by $>50 \%$ phyllosilicate content, well-developed cleavage, and green, grey and black colour. Their mineral assemblage is composed of fine-grained white mica, quartz, chlorite, plagioclase, K-feldspar, and calcite. Rocks with $<50 \%$ phyllosilicates were defined as metapsammites and rocks with $>80 \%$ quartz were classified as quartzites. Metapsammites and quartzites have coarser grain size $(>0.05 \mathrm{~mm})$, less-defined cleavage and an overall grey colour. Their mineral assemblage is composed of quartz, white mica, chlorite, plagioclase and scarce calcite. The low-grade rocks have detrital accessory phases such as ilmenite, zircon, apatite, tourmaline and opaque minerals. No biotite neoblasts were identified in the studied sequence.

Fine-grained white mica (WM) was characterized as the most abundant phyllosilicate phase through Xray diffraction (see section below: Clay-size fraction mineral assemblages) and microscopic observations. Two textural varieties of white mica and chlorite were recognized: $\mathrm{WM}_{1}+\mathrm{Chl}_{1}$ and $\mathrm{WM}_{2}+\mathrm{Chl}_{2}$ (mineral abbreviations follow Kretz, 1983, except WM for white mica), associated to $S_{1}$ and $S_{2}$ respectively. Physical characteristics are similar for both varieties, with grains $<0.03-0.1 \mathrm{~mm}$ long and weak-to-moderate undulose
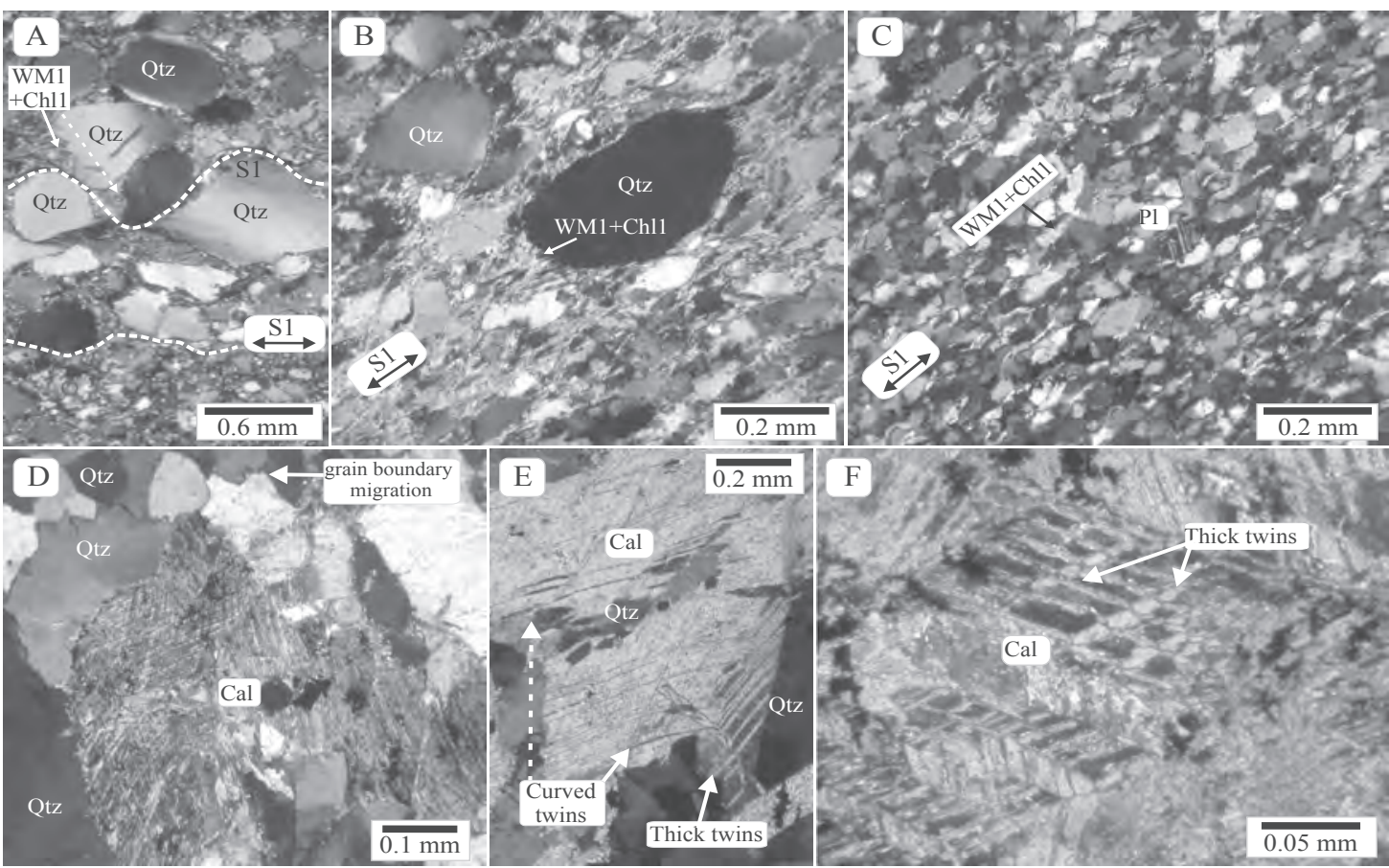

FIG. 4. a-c. Photomicrographs of metapsammites from the quebrada de Cantadero area. a. inequigranular coarse-grained layers showing deformed edges of quartz grains and concave-convex boundaries. $\mathbf{b}$. Continuous foliation $\left(\mathrm{S}_{1}\right)$ defined by aligned $\mathrm{WM}_{1}$ and $\mathrm{Chl}_{1}$. c. Fine-grained layer with preferred orientation of $\mathrm{WM}_{1}$ and $\mathrm{Chl}_{1}$ and grain shape of quartz-plagioclase $\left(\mathrm{S}_{1}\right)$. d-e. Photomicrographs of calcite-quartz veinlets from quebrada de La Cébila area. d. Deformed grains of calcite and quartz. Calcite grains show widened twins, while quartz presents irregular grain boundaries and undulose extinction, consistent with grain boundary migration. e-f. Deformed calcite grains with wide and bent twins. Note the lens-like twin shape and irregular twin boundaries (f). 
extinction. Scarce larger $(<0.4 \mathrm{~mm})$ and irregular shaped muscovite was also identified, with moderate to intense undulose extinction, and is interpreted as detrital. Quartz is anhedral, with grains $<0.1 \mathrm{~mm}$ long in phyllites and $<0.7 \mathrm{~mm}$ long in metapsammites and quartzites. All quartz grains show undulose extinction and irregular grain boundaries related to grain boundary migration (cf. Passchier and Trouw, 2005). Plagioclase $(<0.15 \mathrm{~mm}$ long) displays anhedral grain shapes and polysynthetic twinning; it frequently exhibits weak alteration to fine-grained white mica and kaolinite. K-feldspar appears as scarce thick clasts $(>0.2 \mathrm{~mm})$ surrounded by the fine-grained matrix.

\subsection{Microstructural analysis}

The primary layering $\left(\mathrm{S}_{0}\right)(<1-5 \mathrm{~mm}$ thick in phyllites and $<3-20 \mathrm{~mm}$ in metapsammites) is defined by grain size variations, variable thickness of layers and compositional variations, specifically variable proportions of quartz, feldspar, and phyllosilicates (Figs. 3f, g). In coarse-grained metapsammitic layers the quartz grains show undulose extinction, subgrains and concave-convex boundaries; they could either be associated with inherited features from the protolith, pressure-solution during pre-metamorphic diagenesis, or with the syn-metamorphic development of foliation (Fig. 4a).

Secondary foliations $\left(\mathrm{S}_{1}\right.$ and $\left.\mathrm{S}_{2}\right)$ are well developed in phyllites and weakly developed in metapsammites and quartzites. In phyllites, $\mathrm{S}_{1}$ is defined by oriented $\mathrm{WM}_{1}$ and $\mathrm{Chl}_{1}$ in phyllosilicate layers ( $<1-5 \mathrm{~mm}$ thick) and preferred orientation of quartz and feldspar grainshapes in quartz-feldspatic layers (1-7 $\mathrm{mm}$ thick) (Figs. $3 \mathrm{f}, \mathrm{g})$. In metapsammites and quartzites $\mathrm{S}_{1}$ is defined as a continuous foliation with weak to moderate grainshape orientation of quartz and feldspars with a minor percentage of oriented phyllosilicate minerals (Figs. $4 a, b, c)$.

$\mathrm{S}_{2}$ is less well-developed than $\mathrm{S}_{1}$ and appears as a discrete axial plane foliation due to symmetric to asymmetric crenulation of $S_{1}$ (Figs 3f, g, i, j). $S_{2}$ is defined by oriented blastesis $\mathrm{WM}_{2}$ and $\mathrm{Chl}_{2}$ in thin cleavage domains $(<0.5 \mathrm{~mm}$ thick $)$ alternating with microlithons. However, in the quebrada de La Cébila area $\mathrm{S}_{2}$ is defined by preferential concentration of opaque phases in very thin layers $(<0.1 \mathrm{~mm})$, consistent with dissolution creep processes, and less intense development of blastic white mica (Figs. 3e, g, j). In the quebrada de Cantadero area $\mathrm{S}_{2}$ constitutes a well-developed discontinuous foliation
TABLE 1. SEMIQUANTIFICATION OF CLAY MINERAL PHASES IN THE $<2 \mu \mathrm{m}$ FRACTION OF METASEDIMENTARY SAMPLES FROM LA CÉBILA METAMORPHIC COMPLEX.

\begin{tabular}{lccccc}
\hline Samples & WM & Chl & Sm & Kln & Chl/Vm \\
\hline Quebrada de La & Cébila area & & & \\
CEB-079b & 78 & 22 & - & NQ & - \\
CEB-088 & 83 & 17 & - & - & - \\
CEB-089 & 80 & 20 & - & - & - \\
CEB-090 & 66 & 21 & 12 & - & - \\
QCE-6008 & 81 & 19 & - & - & - \\
Eastern quebrada de Cantadero area & & \\
CAN-020 & 76 & 14 & 24 & - & - \\
CAN-021 & 73 & 27 & - & - & - \\
CAN-025 & 82 & - & - & 18 & - \\
CAN-302 & 42 & - & - & 58 & - \\
CAN-305 & 38 & 11 & - & 51 & - \\
CAN-308 & 39 & 41 & - & 20 & - \\
Central-western & quebrada de Cantadero area & \\
CAN-018 & 61 & 39 & - & - & - \\
CAN-019 & 56 & 27 & 17 & - & - \\
CAN-312 & 83 & 17 & & - & - \\
CAN-314 & NQ & NQ & - & - & NQ \\
CAN-316 & 56 & 44 & - & - & NQ \\
\hline
\end{tabular}

Notes: 1. Abbreviations: vermiculite $(\mathbf{V m})$, smectite (Sm), not quantified (NQ); 2. Values expressed in percentage.

in the eastern sector and is frequently highlighted by iron oxide concentrations (Figs. 3d, f, h, i).

Another feature observed in the metasedimentary rocks is the presence of veinlets ( $<1 \mathrm{~mm}$ thick) which were classified into five types according to their mineral composition: A. quartz veinlet; B. quartz-calcite veinlet; C. calcite veinlet; D. chlorite veinlet (radial habit), and $\mathbf{E}$. veinlets rich in opaque minerals. These veinlets are generally discordant to $\mathrm{S}_{0} / \mathrm{S}_{1}$ and affected by the $\mathrm{D}_{2}$ event associated with $\mathrm{S}_{2}$ development, as is shown by deformed chlorite veinlets (Fig. 3f) and quartz and quartz-calcite veinlets (with deformed twins in calcite, Figs. 4d, e, f). However, veinlets rich in opaque minerals are discordant to concordant to $\mathrm{S}_{2}$, suggesting that they could be contemporaneous with or younger than $\mathrm{D}_{2}$. These opaque veins were observed in macroscopic and microscopic scale (see iron oxide veins in Fig. $3 d$ ). Deformed grains of calcite in quartz-calcite veinlets from quebrada de La Cébila show widened twins, bent twins, lens-like twin shape and irregular twin boundaries (Figs. 4e, f). These twin geometries 

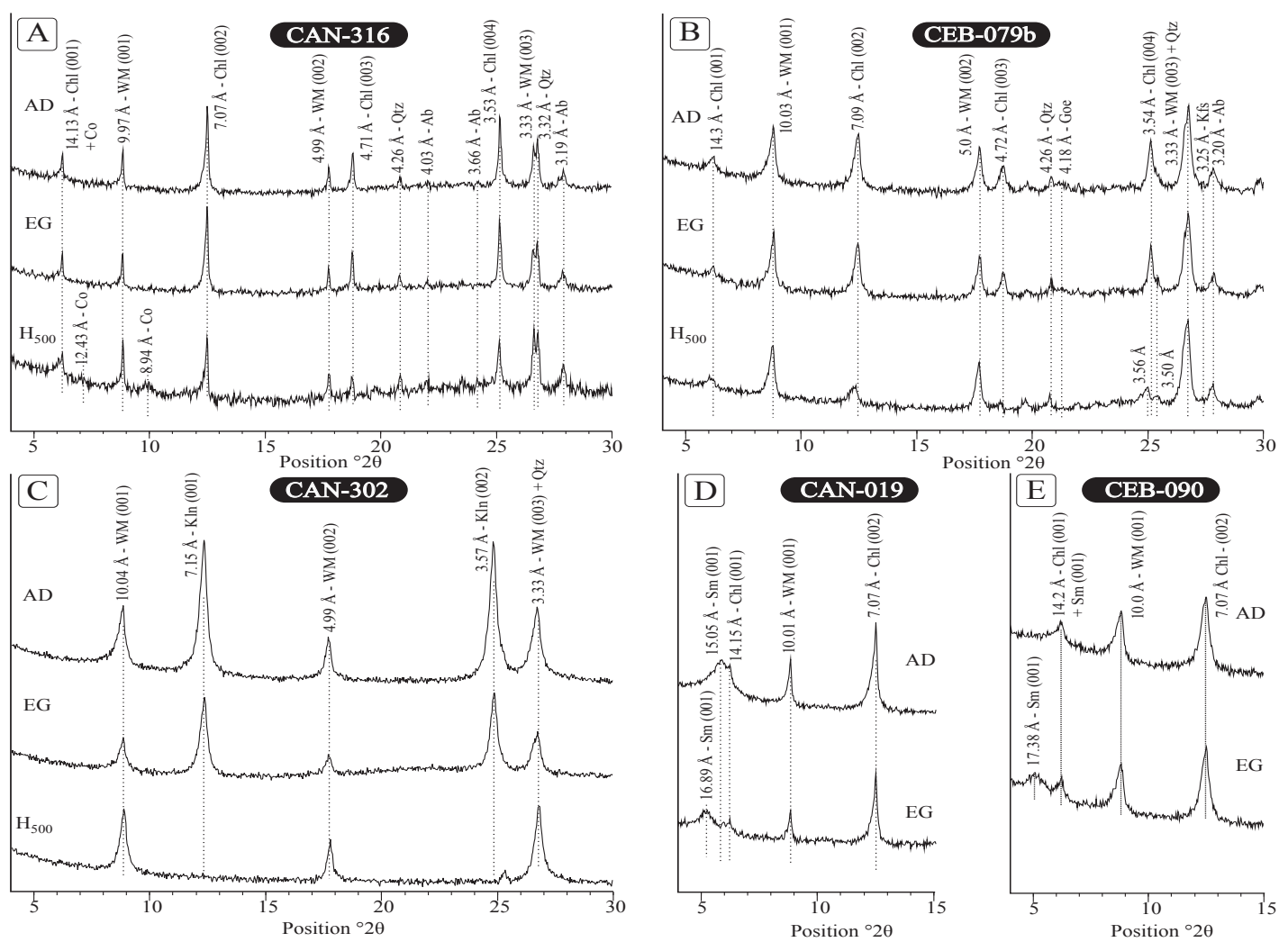

FIG. 5. a, b. Representative X-ray diffraction diagrams of clay-size fraction of low-grade metapelites from the quebrada de Cantadero area (a, sample CAN-316; note the presence of corrensite at $\sim 12.4$ and $\sim 8.9 \AA$ in the H500 diagram) and quebrada de La Cébila area (b, sample CEB-079b); c. X-ray diagrams of sample CAN-302 from the quebrada de Cantadero area. Note the kaolinite reflections at $\sim 7.1$ and $\sim 3.57 \AA$ in the $\mathrm{AD}$, that disappear in the H500 diagram; d. Detailed diagram of sample CAN-019 from the quebrada de Cantadero area showing the appearance of a $\sim 16.9 \AA$ reflection in the EG diagram due to the presence of small amounts of smectite; e. Detailed X-ray diagrams of sample CEB-090 from the quebrada de La Cébila area, showing the presence of an expandable phase (smectite) at $\sim 17.4 \AA$ in the EG diagram.

are transitional between types II and III according to Burkhard (1993) and Ferril et al. (2004).

\subsection{Clay-size fraction mineral assemblages}

The mineralogical composition of the $<2 \mu$ m fraction was determined by X-ray diffraction, with white mica $(38-83 \%$, see Table 1) and chlorite (11-44\%) as the main phyllosilicate phases, plus quartz, albite $(\mathrm{Ab}) \pm \mathrm{K}$ feldspar \pm goethite (Goe) as subordinate phases (Table $2)$. White mica was identified in all samples $(n=17)$ by the presence of the $10.1 \AA(001), 5.0 \AA$ (002) and $3.38 \AA(003)$ reflections in $\mathrm{AD}$ diagrams, that show no modifications in the $\mathrm{EG}$ and $\mathrm{H}_{500}$ diagrams (Figs. 5a, b). Chlorite was identified in most of the samples by the $14.2 \AA(001), 7.1 \AA(002), 4.74 \AA(003)$ and $3.55 \AA$ (004) reflections in the AD diagrams (Figs. 5a, b), that do not show significant modifications in the EG and $\mathrm{H}_{500}$ diagrams. The 4.27 and $3.34 \AA$ reflections were assigned to quartz, and the 3.24 and $3.19 \AA$ reflections were assigned to K-feldspar and albite, respectively.

The appearance of a reflection at $\sim 17 \AA$ in the EG diagrams from three of the samples, together with a lower intensity of the $14.2 \AA$ reflection, indicate the presence of minor amounts of expandable phases such as smectite (Sm, 12-24\%, Figs. 5d, e).

Weak reflections at $\sim 12.4$ and $\sim 8.8 \AA$ were identified in $\mathrm{H}_{500}$ diagram from two samples. This suggests the presence of high-charge corrensite (interstratified chlorite/vermiculite; Co, Fig. 5a). 
TABLE 2. CLAY-SIZE FRACTION MINERAL ASSEMBLAGES, KÜBLER INDEX (KI ${ }_{\text {CIS }}$ ) AND WHITE MICA $b$ PARAMETER FROM LA CÉBILA METAMORPHIC COMPLEX.

\begin{tabular}{|c|c|c|c|c|c|}
\hline \multirow[b]{2}{*}{ Samples } & \multicolumn{2}{|c|}{ Kübler index $\left(\mathrm{KI}_{\mathrm{CIS}}, \Delta^{\circ} \mathbf{2} \theta\right)$} & \multirow{2}{*}{$\begin{array}{c}\text { White mica } \\
\text { b parameter ( }(\AA)\end{array}$} & \multirow{2}{*}{$\begin{array}{l}\text { Mineral assemblage } \\
\qquad(<2 \mu \mathrm{m})\end{array}$} & \multirow{2}{*}{$\begin{array}{l}\text { Presence of } \\
\mathrm{S}_{2} \text { foliation }\end{array}$} \\
\hline & $<2 \mu \mathrm{m}-\mathrm{AD}$ & $<2 \mu \mathrm{m}-\mathrm{EG}$ & & & \\
\hline \multicolumn{6}{|c|}{ La Cébila area } \\
\hline CEB-079B & 0.35 & - & 9.015 & WM, Chl, Qtz, Kfs, Ab, Goe & $\mathrm{S}_{2}$ \\
\hline CEB-088 & 0.43 & 0.42 & 9.019 & WM, Chl, Qtz, Ab, Goe & $\mathrm{S}_{2}$ \\
\hline CEB-089* & 0.40 & 0.39 & 9.020 & WM, Chl, Qtz, Kfs, Ab & $\mathrm{S}_{2}$ \\
\hline CEB-090 & 0.46 & 0.44 & 9.011 & WM, Chl, Qtz, Kfs, Ab, Goe, Sm & $\mathrm{S}_{2}$ \\
\hline QCE-6008 & 0.32 & 0.32 & 9.018 & WM, Chl, Qtz, Ab & $\mathrm{S}_{2}$ \\
\hline \multicolumn{6}{|c|}{ Eastern Cantadero area } \\
\hline CAN-020 & 0.26 & 0.23 & 9.007 & WM, Chl, Qtz, Ab, Goe, Sm & $\mathrm{S}_{2}$ \\
\hline CAN-021 & 0.39 & 0.42 & 9.013 & WM, Kln?, Qtz? & $\mathrm{S}_{2}$ \\
\hline CAN-025 & 0.34 & 0.33 & 9.019 & WM, Chl, Qtz, Kfs, Ab, Sm & $\mathrm{S}_{2}$ \\
\hline CAN-302 & 0.42 & 0.41 & 9.004 & WM, Kln & $\mathrm{S}_{2}$ \\
\hline CAN-305 & 0.39 & 0.38 & 9.010 & WM, Chl, Kln?, Qtz, Ab, Goe & $\mathrm{S}_{2}$ \\
\hline CAN-307 & 0.43 & 0.41 & 9.008 & WM, Chl, Qtz, Kfs, Ab, An, Goe & $\mathrm{S}_{2} ?$ \\
\hline CAN-308* & 0.23 & 0.27 & - & WM, Chl, Kln?, Qtz, Ab, Goe, Sm & - \\
\hline \multicolumn{6}{|c|}{ Central-western Cantadero area } \\
\hline CAN-018 & 0.18 & 0.22 & 9.012 & WM, Chl, Qtz, Kfs, Ab, Goe, Sm & - \\
\hline CAN-019 & 0.22 & 0.24 & 9.017 & WM, Chl, Qtz, Kfs, Ab, Goe, Sm & - \\
\hline CAN-312 & 0.20 & 0.20 & 9.014 & WM, Chl, Qtz, Ab, Goe & - \\
\hline CAN-314 & 0.31 & 0.37 & 9.018 & WM, Chl, Qtz, Kfs, Ab, Goe, Co & $\mathrm{S}_{2}$ \\
\hline CAN-316* & 0.17 & 0.16 & 9.017 & WM, Chl, Qtz, Ab, An, Co & - \\
\hline
\end{tabular}

* $\quad$ Fine-grained metapsammites.

Four samples from the quebrada de Cantadero area show strong reflections at $\sim 7.1$ and $\sim 3.57 \AA$ that disappear or lose intensity in the $\mathrm{H}_{500}$ diagrams, which suggests the presence of kaolinite (Kln, 18-58\%). In most cases this phase is associated with chlorite, although in some samples it appears as the only phase, with a spacing of $\sim 7 \AA$ (Fig. 5c).

In most of the samples a reflection was identified at $\sim 4.2 \AA$ in $\mathrm{AD}$ diagrams, which disappears in the $\mathrm{H}_{500}$ diagrams, suggesting the presence of goethite (Fig. 5b). The occurrence of this mineral species is consistent with macroscopic and microscopic observations of significant quantities of Fe-oxides coatings.

\subsection{Kübler Index}

Kübler indices ( $\mathrm{KI}_{\mathrm{CIS}}$ values) were determined in metapelites and some fine-grained metapsammites. KI values were measured both in air-dried and ethylene glycol-solvated aggregates and similar $\mathrm{KI}_{\mathrm{CIS}}$ values were obtained (Fig. 6a).

Two different $\mathrm{IK}_{\mathrm{CIS}}$ data sets could be distinguished in the quebrada de Cantadero area, broadly corresponding to the eastern and western areas. Those samples showing $\mathrm{D}_{1}\left(\mathrm{~S}_{1}\right)$ but not $\mathrm{D}_{2}\left(\mathrm{~S}_{2}\right)$ structures exhibit $\mathrm{KI}_{\text {CIS }}$ values ranging between 0.23 and $0.17 \Delta^{\circ} 2 \theta$ (mean value of 0.20 and standard deviation of $0.03 ; 95 \%$, $\mathrm{n}=5$ ), indicating epizone conditions (Table 2; Fig. 6a). Samples recording $\mathrm{D}_{2}$ structures $\left(\mathrm{S}_{2}\right)$, mainly from the eastern area, show values ranging between 0.43 and $0.26 \Delta^{\circ} 2 \theta$ (mean value of 0.36 and standard deviation of $0.06 ; 95 \%, n=7)$, characteristic of the late diagenesis-low anchizone transition (Table 2; Fig. 6a). In the quebrada de La Cébila area, where all samples recorded $\mathrm{D}_{2}$ structures $\left(\mathrm{S}_{2}\right)$, similar values $\mathrm{KI}_{\mathrm{CIS}}$ ranging between 0.46 and $0.32 \Delta^{\circ} 2 \theta$ (mean value of $0.39 \Delta^{\circ} 2 \theta$ and 

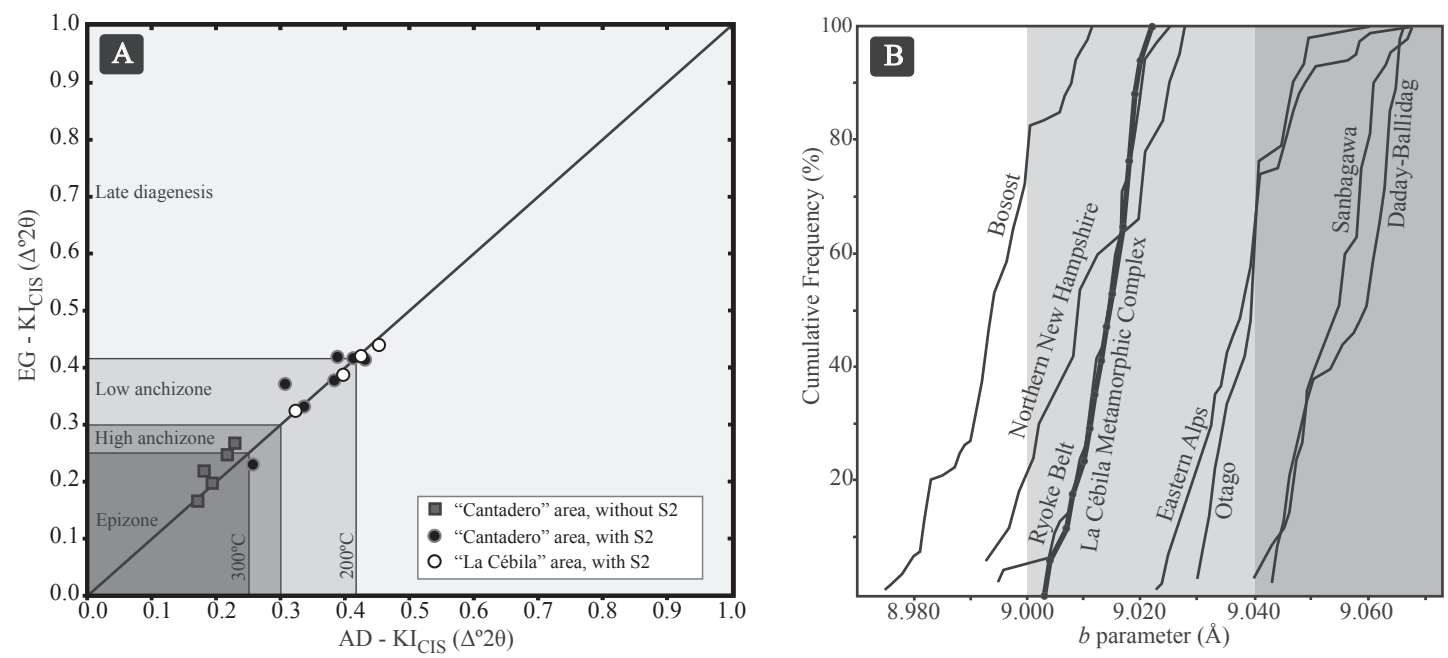

FIG. 6. a. Air-dried (AD) $\mathrm{KI}_{\mathrm{CIS}}$ values plotted against ethylene glycol solvated (EG) values ( $\left.\mathrm{n}=16\right)$. Most of them are near the $1: 1$ ratio line; b. Cumulative frequency curves of white mica $b$ parameter values of La Cébila Metamorphic Complex $(\mathrm{n}=16)$ and different facies series extracted from Sassi and Scolari (1974). Note similarities between curves for La Cébila and the Ryoke Belt, Japan.

standard deviation of $0.06 ; 95 \%, \mathrm{n}=5$ ) were recorded (Table 2; Fig. 6a).

\subsection{White mica $b$ parameter}

The white mica $b$ parameter was measured in most of the samples, and values from 9.004 to $9.022 \AA$ with a mean of $9.014 \AA(0.005 \AA$ standard deviation, confidence level of $95 \%$ and $n=16$, Table 2) were obtained. According to the classification of Guidotti and Sassi (1986), these values are within the range established for intermediate pressure conditions $(9.000$ $9.040 \AA$ ); the minimum value of $9.004 \AA$ would be close to the boundary between intermediate and low pressures. The cumulative frequency curve of the $\mathrm{La}$ Cébila Metamorphic Complex (Fig. 6b) is similar to those obtained for sequences with post-depositional histories developed under low-pressure conditions (see Ryoke Belt in Sassi and Scolari, 1974).

\section{Discussion: Tectono-thermal history and ther- mobarometric conditions for the low-grade metamorphism of the La Cébila Metamorphic Complex}

Petrographical and mineralogical analyses carried out on the low-grade units of La Cébila Metamorphic Complex show at least two white mica growing episodes interpreted as the result of two tectono-thermal events: $\mathrm{M}_{1}-\mathrm{D}_{1}\left(\mathrm{~F}_{1}-\mathrm{S}_{1}\right)$ and $\mathrm{M}_{2}-\mathrm{D}_{2}$ $\left(\mathrm{F}_{2}-\mathrm{S}_{2}\right) \cdot \mathrm{WM}_{1}$ and $\mathrm{Chl}_{1}$ are associated with the main $\mathrm{M}_{1}$ event while $\mathrm{WM}_{2}$ and $\mathrm{Chl}_{2}$ are related to the less developed $\mathrm{M}_{2}$ event.

The age of intrusion of granitic bodies in the medium- to high-grade metasedimentary sequence (e.g., granites from the Antinaco complex; De los Hoyos et al., 2008), together with the Floian sedimentation age (Verdecchia et al., 2007) suggest a Middle Ordovician maximum age for the $\mathrm{M}_{1}-\mathrm{D}_{1}$ event. The discordance between undeformed Ordovician granites and pegmatitic dykes, and the secondary foliation $\left(\mathrm{S}_{1}\right)$ in quebrada de La Cébila (Verdecchia, 2009), allow interpreting the magmatism as postcinematic to $D_{1}$, and the thermal imput related with $M_{1}$ would not be linked with the intrusion of these igneous bodies.

Epizonal conditions established for some samples in the quebrada de Cantadero area are consistent with petrographical observations pointing to a strong development of a spaced cleavage $\left(\mathrm{S}_{1}\right)$, with blastesis of white mica grains larger than $\sim 0.1 \mathrm{~mm}$ (Figs. 3h, j). This type of foliation is generally associated with conditions above the high anchizone (cf. Merriman and Peacor, 1999) and is typical of the epizone. Although the $S_{1}$ foliation is well developed in all analyzed samples, petrographically inconsis- 
tent late-diagenesis to low-anchizone values were obtained within the samples from the quebrada de La Cébila and quebrada de Cantadero areas which also show $\mathrm{S}_{2}$ foliation (Table 2). Compositional variations established through petrography and $\mathrm{XRD}$ analysis (e.g., $\mathrm{Kfs}$ content) are insufficient to explain the different development of phyllosilicate phases during a single metamorphic event $\left(\mathrm{M}_{1}\right)$, as relationships between the compositional variations and $\mathrm{KI}_{\mathrm{CIS}}$ values were not observed. Consequently, variations of $\mathrm{KI}_{\mathrm{CIS}}$ values within the two data sets would not be attributable to compositional variations. Moreover, although the expandable phases identified in the analyzed low-grade rocks could be associated with retrograde diagenesis (cf. Nieto et al., 2005), typical sequences affected by this process do not record alterations in the measured $\mathrm{KI}_{\mathrm{CIS}}$ values (Personal communication, F. Nieto, 2010) and consequently we cannot interpret the inconsistency as a product of retrograde diagenesis. Therefore, high $\mathrm{KI}_{\mathrm{CIS}}$ values are probably related to (a) the existence of a less-developed white mica population (probably associated with the petrographically identified $\mathrm{WM}_{2}$ linked to $\mathrm{M}_{2}$ event) or (b) composite (001) reflections as consequence of the coexistence of $\mathrm{WM}_{1}$ and $\mathrm{WM}_{2}$ (associated with the main $\mathrm{M}_{1}$ and $M_{2}$ events, respectively). In either case, values obtained from those samples that were strongly affected by both events (e.g., presence of both $\mathrm{D}_{1}$ and $\mathrm{D}_{2}$ structures) are inadequate to estimate the thermal conditions linked to the $\mathrm{M}_{1}-\mathrm{D}_{1}$ event. Based on these interpretations, thermal conditions for the $M_{1}-D_{1}$ event were estimated from the samples that were not significantly affected by the $\mathrm{M}_{2}-\mathrm{D}_{2}$ event (see Table 2). The $\mathrm{KI}_{\mathrm{CIS}}$ values of these samples range between 0.17 and $0.23 \Delta^{\circ} 2 \theta$, belonging to the epizone field, suggesting temperatures higher than $300^{\circ} \mathrm{C}$ (cf. Merriman and Frey, 1999) but, as is pointed by the absence of biotite neoblasts, lower than $400^{\circ} \mathrm{C}$ (Spear and Cheney, 1989).

As the $\mathrm{WM}_{1}$ is the dominant phase, we considered the measured $b$ parameter values as representative of the conditions reached by the sequence during the $\mathrm{M}_{1}$ event. Moreover, no difference was found between values obtained in samples that record $\mathrm{D}_{2}$ structures $\left(\mathrm{S}_{2}\right)$ and those only showing $\mathrm{D}_{1}$ structures $\left(\mathrm{S}_{1}\right)$, as well as between samples with and without Kfs (Table 2). Values established for the low-grade rocks of La Cébila Metamorphic Complex (9.004$9.022 \AA$ ) correspond to the intermediate pressure facies series (9.000-9.040 ̊; cf. Guidotti and Sassi,
TABLE 3. CHEMICAL COMPOSITION (a.p.f.u.) OF WHITE MICAS (WM $)$.

\begin{tabular}{|c|c|c|c|c|c|c|}
\hline \multirow{2}{*}{$\begin{array}{c}\text { Sample } \\
\mathrm{Si}\end{array}$} & \multicolumn{3}{|c|}{ CEB-90 } & \multicolumn{3}{|c|}{ CAN-21 } \\
\hline & 3.29 & 3.23 & 3.13 & 3.21 & 3.17 & 3.13 \\
\hline $\mathrm{Al}_{\mathrm{IV}}$ & 0.71 & 0.77 & 0.87 & 0.79 & 0.83 & 0.87 \\
\hline $\mathrm{Al}_{\mathrm{VI}}$ & 1.68 & 1.69 & 1.75 & 1.71 & 1.69 & 1.77 \\
\hline $\mathrm{Fe}$ & 0.14 & 0.12 & 0.12 & 0.14 & 0.14 & 0.09 \\
\hline $\mathrm{Mg}$ & 0.14 & 0.14 & 0.12 & 0.12 & 0.13 & 0.10 \\
\hline $\mathrm{Mn}$ & 0.00 & 0.00 & 0.00 & 0.01 & 0.00 & 0.01 \\
\hline $\mathrm{Ti}$ & 0.03 & 0.02 & 0.03 & 0.03 & 0.03 & 0.03 \\
\hline$\sum$ oct. & 1.98 & 1.98 & 2.01 & 2.00 & 2.01 & 1.99 \\
\hline $\mathrm{K}$ & 0.91 & 0.98 & 0.96 & 0.94 & 0.98 & 0.94 \\
\hline $\mathrm{Na}$ & 0.04 & 0.04 & 0.02 & 0.01 & 0.01 & 0.08 \\
\hline $\mathrm{Ca}$ & 0.00 & 0.00 & 0.00 & 0.00 & 0.00 & 0.00 \\
\hline$\sum$ int. & 0.96 & 1.02 & 0.98 & 0.95 & 0.98 & 1.02 \\
\hline Al Tot. & 2.38 & 2.46 & 2.62 & 2.50 & 2.52 & 2.63 \\
\hline $\begin{array}{l}\text { Pressure } \\
\text { (Mpa) * }\end{array}$ & 300 & 200 & $<100$ & 180 & 110 & $<100$ \\
\hline
\end{tabular}

Notes: 1. Normalized to 11 oxygens; 2. Fe content calculated with $45 \%$ of $\mathrm{Fe}^{3+}$ as suggested by Guidotti et al. (1994) for ilmenite-bearing samples; 3. *Minimum pressure ranges estimated from phengite geobarometer of Massonne and Szpurka (1997) considering $350^{\circ} \mathrm{C}$.

1986), although it is clear that most of the values are below the average established for this field (9.020 $)$. Comparison of the results obtained in this work with the cumulative frequency curves published by Sassi and Scolari (1974) for typical low-, medium- and high- pressure metamorphic environments, suggests that the low-grade rocks within La Cébila Metamorphic Complex were metamorphosed at least in the lowto intermediate-pressure transition. EDX analyses of $\mathrm{WM}_{1}$ (Table 3) show Si contents between 3.13 to 3.29 a.p.f.u. (atom per formula unit) that suggest minimum pressure conditions between $<100$ and $300 \mathrm{MPa}$ (Massone and Szpurka, 1997) assuming an average temperature of $350^{\circ} \mathrm{C}$. The estimated conditions are also supported by the similarity between La Cébila Metamorphic Complex and Ryoke Belt (Japan) white mica $b$ parameters (Fig. 6b), the latter having been interpreted as a classical low-pressure regional metamorphic complex (cf. Brown, 1998). Furthermore, pressure and temperature conditions estimated in this work for the $\mathrm{M}_{1}-\mathrm{D}_{1}$ event in lowgrade rocks from La Cébila Metamorphic Complex are consistent with the conditions established in higher-grade sequences located immediately to the west. The metamorphic zonation in medium- to high-grade metamorphic rocks from this complex showed andalusite-cordierite, sillimanite-K-feldspar, 
cordierite-K-feldspar parageneses, interpreted as product of regional low-pressure metamorphism (Verdecchia, 2009).

Consequently, the $M_{1}-D_{1}$ event could be interpreted as part of an Ordovician regional low-pressure metamorphic event associated with a high thermal gradient. The thermobarometric conditions here estimated for low-grade rocks from La Cébila Metamorphic Complex are similar to those from most of the Ordovician metamorphic complexes belonging to the Argentinian Famatinian foreland area within the Sierras Pampeanas (high-temperature and low-pressure, e.g., sierra de Paganzo, Los Llanos-Chepes-Ulapes, Pringles Complex in sierra de San Luis, sierra de Quilmes; see Fig. 1a; Saal et al, 1996; Pascua, 1998; Dahlquist et al., 2005; Steenken et al., 2006; Delpino et al., 2007; Büttner et al., 2005). In the metamorphic complexes of sierras de San Luis (Pringles Complex) and sierras de ChepesUlapes-Los Llanos, main Early Paleozoic metamorphic events were interpreted as consequence of high-strain heating in a compressive context, that would have been subsequent to the back-arc basin extension (e.g., Dahlquist and Galindo, 2004; Dahlquist et al., 2005; Steenken et al., 2006).

The $\mathrm{M}_{2}-\mathrm{D}_{2}$ represents a tectono-metamorphic event subsequent and subordinate to the main $\mathrm{M}_{1}-\mathrm{D}_{1}$. It is characterized by a weak compressional episode that develops folds and a weak secondary foliation with similar main stress direction than the $\mathrm{D}_{1}$ structures. Temperatures of $\sim 180-270^{\circ} \mathrm{C}$ estimated from $\mathrm{KI}_{\text {CIS }}$ values ranging between 0.31 and $0.46 \Delta^{\circ} 2 \theta$ in samples with white mica blastesis associated to $\mathrm{S}_{2}$, could be considered as maximum temperatures linked with the $\mathrm{M}_{2}$ event. In addition, the calcite twins described in quartz-calcite veins from quebrada de La Cébila area (II-III type) suggest a deformation temperature $\left(\mathrm{D}_{2}\right)$ of $\sim 200-300^{\circ} \mathrm{C}$.

Temperatures estimated for the $M_{1}$ and $M_{2}$ events would imply that the small amounts of smectite, corrensite and kaolinite identified in some samples could be related to subsequent retrograde diagenesis (Nieto et al., 2005) given the instability of some of these phases above $\sim 180^{\circ} \mathrm{C}$.

\section{Conclusions}

Petrographical analysis of the low-grade metamorphic successions from La Cébila Metamorphic Complex allows establishing at least two with mica growth episodes associated with the development of secondary foliations $\left(\mathrm{S}_{1}\right.$ and $\left.\mathrm{S}_{2}\right)$ and related to two tectono-thermal events $\left(\mathrm{M}_{1}-\mathrm{D}_{1}\right.$ and $\left.\mathrm{M}_{2}-\mathrm{D}_{2}\right)$. Clay minerals analysis, Kübler indices, white mica $b$ parameter values and $\mathrm{Si}$ contents enable the estimation of temperatures between 300 and $400^{\circ} \mathrm{C}$ and low-pressure conditions for the $\mathrm{M}_{1}$ metamorphic event in the low-grade metasedimentary rocks from La Cébila Metamorphic Complex. Temperatures of $\sim 180-270^{\circ} \mathrm{C}$ are estimated for the $\mathrm{M}_{2}$ event. A subsequent retrograde diagenetic episode is recorded, with formation of associated expandable clay phases. The tectono-thermal $\mathrm{M}_{1}-\mathrm{D}_{1}$ event recorded in this complex could be linked with the low-pressure metamorphism recorded in others complexes from Sierras Pampeanas where the metamorphic event was associated to an Ordovician high-strain heating stage.

\section{Acknowledgements}

We thank the Centro Regional de Investigaciones Científicas y Transferencia Tecnológica (CRILAR) for providing logistic support, and SPECTRAU laboratory (University of Johannesburg), Instituto de Geocronología y Geología Isotópica (INGEIS, Universidad de Buenos Aires) and Facultad de Ciencias Químicas (Universidad Nacional de Córdoba) for given us access to their facilities. Financial support for this paper was provided by Argentine public grants FONCyT PICT-1009 (Fondo para la Investigación Científica y Tecnológica) and CONICET PIP-1940 (Consejo Nacional de Investigaciones Científicas y Técnicas). We are grateful to Drs. F. Nieto, M. Do Campo, R. Pankhurst and F. Colombo for suggestions on several aspects of the manuscript. Dra. Brime and one anonymous reviewer are thanked for their constructive comments that enabled us to improve the manuscript.

\section{References}

Aceñolaza, G.F.; Toselli, A.J. 1976. Consideraciones estratigráficas y tectónicas sobre el Paleozoico Inferior del Noroeste Argentino. In Congreso Latinoamericano de Geología, No. 2: 755-764. Caracas.

Aceñolaza, F.G.; Miller, H.; Toselli, A.J. 2002. ProterozoicEarly Paleozoic evolution in western South America-a discussion. Tectonophysics 354 (1-2): 121-137.

Astini, R.A. 2003. The Ordovician proto-Andean basins. In Ordovician fossils of Argentina (Benedetto, J.L.; editor). Secretaría de Ciencia y Tecnología, Universidad Nacional de Córdoba: 1-74.

Astini, R.A.; Dávila, F.M. 2004. Ordovician back arc foreland and Ocloyic thrust belt development on the western Gondwana margin as a response to Precordillera terrane accretion. Tectonics 23: TC4008. DOI:10.1029/28 2003TC001620. 
Astini, R.A.; Dávila, F.M.; Collo, G.; Martina, F. 2004. La Formación La Aguadita (Ordovícico mediosuperior): Su implicancia en la evolución temprana del Famatina y como parte del orógeno oclóyico en el noroeste argentino. In Geología de la Provincia de La Rioja, Precámbrico-Paleozoico Inferior (Dahlquist, J.A.; Baldo, E.G.; Alasino P.H.; editors). Asociación Geológica Argentina, Serie D 8: 67-84.

Bahlburg, H. 1991. The Ordovician back-arc to forelands successor basin in the Argentinian-Chilean Puna: tectono-sedimentary trends and sea-level changes. International Association of Sedimentologists, Special Publication 12: 465-484.

Baldo, E.; Casquet, C.; Pankhurst, R.J.; Galindo, C.; Rapela, C.W.; Fanning, C.M.; Dahlquist, J.; Murra, J. 2006. Neoproterozoic A-type magmatism in the Western Sierras Pampeanas (Argentina): evidence for Rodinia break-up along a proto-Iapetus rift? Terra Nova 18: 388-394.

Brown, M. 1998. Unpairing metamorphic belts: P-T paths and a tectonic model for the Ryoke Belt, Southwest Japan. Journal of Metamorphic Geology 16: 3-22.

Burkhard, M. 1993. Calcite twins, their geometry, appearance and significance as stress-strain markers and indicators of tectonic regime: a review. Journal of Structural Geology 15: 351-368.

Büttner, S.H.; Glodny, J.; Lucassen, F.; Wemmer, K.; Erdmann, S.; Handler, R.; Franz, G. 2005. Ordovician metamorphism and plutonism in the Sierra de Quilmes metamorphic complex: Implications for the tectonic setting of the northern Sierras Pampeanas (NW Argentina). Lithos 83: 143-181.

Büttner, S.H. 2009. The Ordovician Sierras Pampeanas-Puna basin connection: Basement thinning and basin formation in the Proto-Andean back-arc. Tectonophysics 3-4: 278-291.

Chew, D.M.; Schaltegger, U.; Košler, J.; Whitehouse, M.J.; Gutjahr, M.; Spikings, R.A.; Miškovic A. 2007. U-Pb geochronologic evidence for the evolution of the Gondwanan margin of the northcentral Andes. Geological Society of America Bulletin 119: 697-711.

Coira, B.; Koukharsky, M.; Ribeiro Guevara, S.; Cisterna, C.E. 2009. Puna (Argentina) and northern Chile Ordovician basic magmatism: A contribution to the tectonic setting. Journal of South American Earth Sciences 27: 24-35.

Collo, G.; Astini, R.A.; Cardona, A.; Do Campo, M.D.; Cordani, U. 2008. Edad del metamorfismo de las unidades con bajo grado de la región central del Famatina: La impronta del ciclo orogénico oclóyico. Revista Geológica de Chile 35 (2): 191-213.

Dahlquist, J.; Galindo, C. 2004. Geoquímica isotópica de los granitoides de la Sierra de Chepes. Un modelo geotectónico y termal: implicancias para el Orógeno Famatiniano. Revista de la Asociación Geológica Argentina 59: 57-69.

Dahlquist, J.; Rapela, C.; Baldo, E. 2005. Cordierite-bearing S-Type granitoids in the Sierra de Chepes (Sierras Pampeanas): Petrogenetic Implications. Journal of South American Earth Sciences 20: 231-251.

Dahlquist, J.A.; Pankhurst, R.J.; Rapela, C.W.; Casquet, C.; Fanning, C.M.; Alasino, P.; Báez, M.A. 2006. The San Blas Pluton: An example of Carboniferous plutonism in the Sierras Pampeanas, Argentina. Journal of South American Earth Sciences 20: 341-350.

Dahlquist, J.A.; Pankhurst, R.J.; Rapela, C.W.; Galindo, C.; Alasino, P.; Fanning, C.M.; Saavedra, J.; Baldo, E. 2008. New SHRIMP U-Pb data from the Famatina Complex: constraining Early-Mid Ordovician Famatinian magmatism in the Sierras Pampeanas, Argentina. Geologica Acta 6: 319-333.

De los Hoyos, C.R.; Basei, M.A.; Rossi, J.N.; Toselli, A.J. 2008. Four new ID-TIMS U-Pb monazite ages for deformed and undeformed granitoids in the eastern sector of the Velasco range, Sierras Pampeanas, Argentina. In South American Symposium on Isotope Geology, No. 6, Extended Abstracts Volume in CD-ROM: 6 p.

Delpino, S.H.; Bjerg, E.A.; Ferracutti, G.R.; Mogessie, A. 2007. Counterclockwise tectonometamorphic evolution of the Pringles Metamorphic Complex, Sierras Pampeanas of San Luis (Argentina). Journal of South Earth American Sciences 23: 147-175.

Espizúa, L.; Caminos, R. 1979. Las rocas metamórficas de la Formación La Cébila, Sierra de Ambato, provincias de Catamarca y La Rioja. Boletín de la Academia Nacional de Ciencias de Córdoba, Argentina 53 (1-2): 125-142.

Ferrill, D.A.; Morris, P.A.; Evans, M.A.; Burkhard, M.; Groshong Jr., R.H.; Onasch, C.M. 2004. Calcite twin morphology: a low-temperature deformation geothermometer. Journal of Structural Geology 26: 1521-1529.

González Bonorino, F. 1951. Una nueva Formación Precámbrica en el Noroeste Argentino. Comunicación Científica, Museo de La Plata 5: 4-6.

Guidotti, C.V.; Sassi, F.P. 1986. Classification and correlation of metamorphic facies series by means of musovite $b_{0}$ data from low grade metapelites. Neues Jahrbuch für Mineralogie Abhandlungen 153 (3): 363-380.

Guidotti, C.V.; Yates, M.G.; Dyar, M.D.; Taylor, M.A. 1994. Petrogenetic implications of Fe3+ content of muscovite in pelitic schists. American Mineralogist 79: 793-795.

Grosse, P.; Söllner, F.; Báez, M.; Toselli, A.J.; Rossi, J.N.; De la Rosa, J. 2008. Lower Carboniferous post-orogenic granites in central-eastern Sierra de Velasco, Sierras 
Pampeanas, Argentina: U-Pb monazite geochronology, geochemistry and $\mathrm{Sr}-\mathrm{Nd}$ isotopes. International Journal of Earth Sciences. DOI: 10.1007/s00531-007-0297-5.

Gutiérrez, P.R.; Barreda, V.D. 2006. Palinología de la Formación El Trampeadero (Carbonífero Superior), La Rioja, Argentina: significado bioestratigráfico. Ameghiniana 43 (1): 71-84.

Kisch, H.J. 1991. Illite crystallinity: recommendations on sample preparation, X-ray diffraction settings and interlaboratory settings. Journal of Metamorphic Geology 9: 665-670.

Kretz, R. 1983. Symbols for rock-forming minerals. American Mineralogist 68: 277-279.

Kübler, B. 1968. Evaluation quantitative du métamorphisme par la cristallinité de I'llite; etat des progres realises ces dernieres annees. Bulletin du Centre de Recherches de Pau-Societe Nationale des Petroles d'Aquitaine (SNPA) 2: 385-397.

Lucassen, F.; Becchio, R.; Wilke, H.G.; Thirwall, M.F.; Viramonte, J.; Franz, G.; Wemmer, K. 2000. ProterozoicPaleozoic development of the basement of the Central Andes (18-26) -a mobile belt of the South American craton. Journal of South American Earth Sciences 13: 697-715.

Masonne, H.J.; Szpurka, Z. 1997. Thermodynamic properties of white micas on the basis of high-pressure experiments in the systems $\mathrm{K}_{2} \mathrm{O}-\mathrm{MgO}-\mathrm{Al}_{2} \mathrm{O}_{3}-\mathrm{SiO}_{2}-\mathrm{H}_{2} \mathrm{O}$ and $\mathrm{K}_{2} \mathrm{O}-\mathrm{FeO}-\mathrm{Al}_{2} \mathrm{O}_{3}-\mathrm{SiO}_{2}-\mathrm{H}_{2} \mathrm{O}$. Lithos 41: 229-250.

Merriman, R.J.; Frey, M. 1999. Patterns of very low-grade metamorphism in metapelitic rocks. In Low-Grade Metamorphism (Frey, M.; Robinson, D.; editors), Blackwell Science: 61-107.

Merriman, R.J.; Peacor, D.R. 1999. Very low grade metapelites: Mineralogy, microfabrics and measuring reaction progress. In Low-Grade Metamorphism (Frey, M.; Robinson, D.; editors). Blackwell Science: 10-60.

Moore, D.M.; Reynolds, R.C. 1997. X-Ray diffraction and the identification and analysis of clay minerals. Oxford University Press: 378 p.

Murra, J.; Baldo, E. 2006. El metamorfismo de las rocas básicas y ultrabásicas de la Sierra de La Huerta-Las Imanas (Sierras Pampeanas, Argentina): caracterización tectonotérmica del margen occidental del orógeno $\mathrm{Fa}$ matiniano. Revista Geológica de Chile 33 (2): 277-298.

Nieto, F.; Mata, P.M.; Bauluz, B.; Giorgetti, G.; Árkai, P.; Peacor, D.R. 2005. Retrograde diagenesis, a widespread process on a regional scale. Clay Minerals 40: 93-104.

Ogg, G. 2009. Stratigraphic chart. International commission on stratigraphy (ICS), International Union of Geological Sciences (IUGS). http://www.stratigraphy.org.

Otamendi, J.E.; Tibaldi, A.M.; Vujovich, G.I.; Viñao, G.A. 2008. Metamorphic evolution of migmatites from the deep Famatinian arc crust exposed in Sierras Valle Fértil-La Huerta, San Juan, Argentina. Journal of South American Earth Sciences 25: 313-335.

Pankhurst, R.J.; Rapela, C.W. 1998. The Proto-Andean Margin of Gondwana: An Introduction. In The ProtoAndean Margin of Gondwana (Pankhurst, R.J.; Rapela, C.W.; editors). Geological Society of London Special Publication 142: 1-9.

Pankhurst, R.; Rapela, C.; Fanning, C. 2000. Age and origin of coeval TTG, I- and S-type granites in the Famatinian belt of NW Argentina. Transactions of the Royal Society of Edinburgh, Earth Sciences 91: 151-168.

Pascua, I. 1998. Petrología y Geoquímica de la Sierra de Los Llanos, Provincia de La Rioja, República Argentina. Ph.D. Thesis (Unpublished), Universidad de Salamanca: 236 p. España.

Passchier, C.W.; Trouw, R.A.J. 2005. Microtectonics. Springer-Verlag: 289 p.

Ramos, V.A. 2008. The basement of the Central Andes: the Arequipa and related terranes. Annual Review of Earth and Planetary Sciences 36: 289-324.

Rapela, C.W.; Pankhurst, R.J.; Casquet, C.; Baldo, E.; Saavedra, J.; Galindo, C. 1998. Early evolution of the proto-Andean margin of South America. Geology 26: 707-710.

Rapela, C.W.; Casquet, C.; Baldo, E.G.; Dahlquist, J.; Pankhurst, R.J.; Galindo, C.; Saavedra, J. 2001. Las Orogénesis del Paleozoico inferior en el Margen Proto-Andino de América del Sur, Sierras Pampeanas Argentinas. Journal of Iberian Geology 27: 23-41.

Rapela, C.; Pankhurst, R.; Casquet, C.; Fanning, C.; Baldo, E.; González-Casado, J.; Galindo, C.; Dahlquist, J. 2007. The Río de la Plata craton and the assembly of SW Gondwana. Earth-Science Reviews 83: 49-82.

Saal, A.; Toselli, A.J.; Rossi de Toselli, J.N. 1996. Granitoides y rocas básicas de la Sierra de Paganzo. In Geología del Sistema de Famatina (Aceñolaza, F.G.; Miller, H.; Toselli, A.J.; editors), Münchner Geologische Hefte A19: 199-209.

Sassi, F.P. 1972. The petrological and geological significance of the bo values of potassic white micas in low-grade metamorphic rocks. An application to the Eastern Alps. Tschermaks Mineralogische und Petrographische Mitteilungen 18: 105-113.

Sassi, F.; Scolari, A. 1974. The $b_{0}$ of the potassic white micas as a barometric indicator in low-grade metamorphism of pelitic schist. Contributions to Mineralogy and Petrology 45: 143-152.

Spear, F.S.; Cheney, J.T. 1989. A petrogenetic grid for pelitic schists in the system $\mathrm{SiO}_{2}-\mathrm{Al}_{2} \mathrm{O}_{3}-\mathrm{FeO}-\mathrm{MgO}$ - 
$\mathrm{K}_{2} \mathrm{O}-\mathrm{H}_{2} \mathrm{O}$. Contributions to Mineralogy and Petrology 101: 149-164.

Steenken, A.; Siegesmund, S.; López de Luchi, M.G.; Frei, R.; Wemmer, K. 2006. Neoproterozoic to Early Palaeozoic events in the Sierra de San Luis: implications for the Famatinian geodynamics in the Eastern Sierras Pampeanas (Argentina). Journal of the Geological Society 163: 965-982.

Thomas, W.A.; Astini, R.A. 1996. The Argentine Precordillera: a traveler from the Ouachita embayment of North America Laurentia. Science 273: 752-757.

Toselli, A.J.; Miller, H.; Aceñolaza, F.G.; Rossi, J.N.; Söllner, F. 2007. The Sierra de Velasco (northwestern Argentina) -an example for polyphase magmatism at the margin of Gondwana. Neues Jahrbuch für Geologie und Paläontologie-Abhandlungen 246 (3): 325-345.

Verdecchia, S.O. 2009. Las metamorfitas de baja presión vinculadas al arco magmático famatiniano: las unidades metamórficas de la quebrada de La Cébila y el borde oriental del Velasco. Provincia de La Rioja, Argentina. Ph.D. Thesis (Unpublished), Universidad Nacional de Córdoba: 312 p. Argentina.

Verdecchia, S.O.; Baldo, E.G. 2010. Geoquímica y procedencia de los metasedimentos ordovícicos del complejo metamórfico La Cébila, Provincia de La Rioja, Argentina. Revista Mexicana de Ciencias Geológicas 27 (1): 97-111.

Verdecchia, S.O.; Baldo, E.G.; Benedetto, J.L.; Borghi, P.A. 2007. The first shelly faunas from metamorphic rocks of the Sierras Pampeanas (La Cébila Formation, Sierra de Ambato, Argentina): age and paleogeographic implications. Ameghiniana 44 (2): 493-498.

Viramonte, J.M.; Becchio, R.; Viramonte, J.G.; Pimentel, M.; Martino, R. 2007. Ordovician igneous and metamorphic units in southeastern Puna: new U-Pb and Sm-Nd data and implications for the evolution of northwestern Argentina. Journal of South American Earth Sciences 24: 167-183.

Warr, L.N.; Rice, A.H.N. 1994. Interlaboratory standardization and calibration of clay mineral cristallinity and cristallite size data. Journal of Metamorphic Geology 12: 141-152.

Zimmermann, U. 2005. Provenance studies of very low to low-grade metasedimentary rocks of the Puncoviscana Complex, northwest Argentina. In Terrane Processes at the margins of Gondwana (Vaughan, A.P.M.; Leat, P.T.; Pankhurst, R.J.; editors). Special Publication of Geological Society of London 246: 381-416.

Manuscript received: May 28, 2010; revised/accepted: November 5, 2010; available online: March 23, 2011 